This PDF is governed by copyright law, which prohibits unauthorised copying, distribution, public display, public performance, and preparation of derivative works.

THIS CHAPTER New Perspectives on Human Security

IS AN EXCERPT

FROM

New

Perspectives

on Human

Security

EDITED BY Malcolm Mclntosh and Alan Hunter

FIRST PUBLISHED

October 2010

ISBN

978-1-906093-41-9 (hbk)

MORE DETAILS AT

www.greenleaf-publishing.com/security

(C) 2010 Greenleaf Publishing Limited 


\title{
1
}

\section{Perspectives on human security The emergent construct}

\author{
Malcolm Mclntosh \\ Asia Pacific Centre for Sustainable Enterprise, Griffith University, Australia
}

\section{Alan Hunter}

Centre for Peace and Reconciliation Studies, Coventry University, UK

This book is testimony to the emergent nature of human security as an idea, as a useful construct and as an operational strategy. Our aim is to showcase new directions that may, we believe, enrich the human security agenda at the time of writing in 2010. Some human security discourse is still rooted in the traditional language of the aid-agency/UN development/economic growth models that emerged from the 1950s onwards, often hostile to the corporate and business sector, and sometimes negligent of environment, sustainability and climate change issues. Another limited and, in our opinion, outmoded approach, is an exaggerated focus on Western interventions, especially military ones, as a 'solution' to problems in poor or conflict-prone areas. Various synopses and analyses of current thinking on human security have already been published, including an accessible account from the United Nations Development Programme (UNDP) (Jolly and Ray 2006). A report for the UN Centre for Regional Development from the early years of the millennium provides another good overview of human security (Mani 2002). Several major Internet-based resources provide regular updates: for example, the excellent Human Security Gateway maintained in Vancouver.

We believe that proponents of a human security approach should welcome efforts to remove the barriers between enterprise, corporates, aid and develop- 
ment agencies, government agencies, citizen groups and the UN; and work towards multi-stakeholder approaches to vulnerable populations. We also believe that such an approach is vital in responding to the imperative of action on climate change. There are several reasons why businesses may want to engage with the needs of vulnerable populations: companies need secure trading environments; they may also have corporate citizenship drivers which induce them to respond positively to customer, shareholder and employee concerns; and many consumers are interested in fair trade, peace and social justice as well as green issues.

\section{The human security lens}

The term 'human security' was first used by the UN in its Human Development Report 1994. In reality it was an idea whose time had come as a result of the evolution of thinking on human security, as opposed to international and state security: an evolution that gathered strength after the First World War, after the Depression of the 1930s, during the Second World War and as part of pre-post-industrial reckoning in democratic societies on both sides of the Atlantic and around the world. Looking back further, one can trace the origins of human security concerns to religious and early socialist ideals of community or commonwealth; and to Roman and Prussian, among other, state ideals of national security, law and order. In the UK such ideals formed the foundations of the National Health Service with the provision of healthcare free at the point of delivery to all, while in the US it led to the New Deal. On 6 January 1941 US President Franklin D. Roosevelt made a speech in which he talked about the 'Four Freedoms': freedom of expression and religion; freedom from want and fear. His wife Eleanor used the ideas and some of the language of this speech in the preamble to the UN's 1948 Universal Declaration of Human Rights when she said that these four freedoms were the 'highest aspirations of the common people'. ${ }^{1}$ Many of the humanitarian concerns were indeed encapsulated in the Universal Declaration of Human Rights itself, Article 25:

Everyone has the right to a standard of living adequate for the health and well-being of himself and of his family, including food, clothing, housing and medical care and necessary social services, and the right to security in the event of unemployment, sickness, disability, widowhood, old age or other lack of livelihood in circumstances beyond his control.

Human security is thus a potentially useful collocation: one word, security, carrying implications of realpolitik and law-enforcement; the other, human, with its connotations of the humanitarian tradition and a person-centred priority.

Human security has three primary components: the sanctity of the individual; the relationship of the individual to the community; and the preservation of peo- 
ple and communities in the face of national, international and global interventions. In 2003 the UN Commission on Human Security, chaired by Sadako Ogata and Amartya Sen, reported that the world needed 'a new security framework that centers directly on people'. Human security, the Commission argued, 'focuses on shielding people from critical and pervasive threats and empowering them to take charge of their lives'. The necessity of paradigm shift is because there is:

a consensus that the meaning of security is eroding; existing institutions and policies [are] unable to cope with weakening multilateralism and global responsibilities. The state has the primary responsibility for security, but the security challenge is complex and various new actors attempt to play a role. ${ }^{2}$

The Commission sought to develop a global framework focused on 'survival, dignity and livelihood; freedom from fear; and freedom from want'. Of particular concern were the most vulnerable individuals who need protection from violent conflict; those people who are on the move; those people who are economically insecure because the global economic system has failed them; or whose lives have been destabilised by forces far beyond their control (Commission on Human Security 2003).

The concept of security has until now tended to be shaped by the potential for conflict between states and this has often meant that security has been equated with the threats to a country's borders. Traditional approaches to security issues tend to focus on military security and are over-concerned with territorial issues. Now, however, economic globalisation and open, global, social networks mean that the professional worlds of humanitarianism, development, human rights, conflict and business must find space to meet and integrate. Human security therefore calls on all partners (business, government, civil society and individuals) to find ways to develop a new paradigm of sustainable human development. But the paradigm shift is from the nation to the individual. As the UNDP Human Development Report 1994 states:

For most people today a feeling of insecurity arises more from worries about daily life than the dread of a cataclysmic world event. Job security, income security, health security, environmental security and security from crime-these are emerging concerns of human security all over the world (UNDP 1994).

In the past decade, Canada, Japan, Norway, the Netherlands and several other states began to use the rubric of 'human security' to introduce a number of new emphases in foreign policy and international work. In summary, they tended to argue that:

- The main reference point for security should be the individual, or the individual in a group or community; and particularly vulnerable people.

2 For UN statements on human security, see McIntosh 2006. 


\section{Box 1.1 Defining human security}

"survival, dignity and livelihood, freedom from fear...freedom from want...

a new security framework that centers directly on people . . human security focuses on shielding people from critical and pervasive threats and empowering them to take charge of their lives ... the consensus on the meaning of security is eroding ... existing institutions and policies unable to cope with weakening multilateralism and global responsibilities... the state has the primary responsibility for security, but the security challenge is complex and various new actors attempt to play a role ... so we need a shift in paradigm.

Protecting peopleinviolentconflict; protecting and empowering peopleon the move; protecting and empowering people in post-conflict situations; economic insecurity - choices in a world of opportunity; health for human security; knowledge, skills and values - for human security; [and] linking the many initiatives.

The Report introduces a new concept of human security, which equates security with people rather than territories, with development rather than arms. It examines both the national and the global concerns of human security. The Report seeks to deal with these concerns through a new paradigm of sustainable human development, capturing the potential peace dividend, a new form of development co-operation and a restructured system of global institutions. For too long the concept of security has been shaped by the potential for conflict between states. For too long, security has been equated with the threats to a country's borders. For too long nations have sought arms to protect their security" (UN Commission on Human Security [2003] chaired by Sadako Ogata and Amartya Sen).

"A humane world where people can live in security and dignity, free from poverty and despair, is still a dream for many and should be enjoyed by all. In such a world, every individual would be guaranteed freedom from fear and freedom from want, with an equal opportunity to fully develop their human potential. Building human security is essential to achieving this goal. In essence, human security means freedom from pervasive threats to people's rights, their safety or even their lives" (UNDP 1994).

Military security of nation states remains important but is not always the overriding priority in every situation

- Individuals or groups are subject to a variety of threats, of which military threats from outside the state are only one and often not the most significant

- The international community has a responsibility in some circumstances to protect vulnerable individuals and communities

- The protection of vulnerable individuals and communities should sometimes take precedence over territorial issues, so in some cases there is possible tension between the security of the individual and that of the nation, the state or the regime 
One influential official document reflecting these concerns was 'Responsibility to Protect', produced by an agency working for the Canadian government (Evan et al. 2001), which tried to evaluate the criteria by which cross-border interventions should be not only permitted, but morally obligatory. The discussion was informed by the perceived failure of the international community to intervene in genocides or near-genocides in Rwanda and Bosnia; and more lately in Darfur. The Responsibility to Protect doctrine was ultimately adopted as a United Nations Security Council Resolution, 1674, in 2006. Some recent publications focus mainly on similar issues (Kaldor 2007).

\section{Human security in the 'developed world'}

This collection also poses the question: is the concept of human security relevant to city, or indeed any, life in developed countries? Arguably it is, since citizens in any state may feel vulnerable to serious crime, marginalisation, terrorism or other problems. In August 2006, for example, Italians were shocked to discover the extent of marginalisation and mutual antipathy between immigrants and local residents in the affluent city of Padua...

... renowned for its ancient university and medieval frescoes by Giotto. Yesterday, however, it acquired a less attractive claim to fame: a steel wall, $84 \mathrm{~m}$ long and $3 \mathrm{~m}$ high, blocking off a run-down housing estate with a high immigrant population and a reputation for drugs, violence and prostitution (Owen 2006).

Other EU states, among the most affluent countries in the world, had recently seen serious problems: violent riots in France, bombings in London.

Another issue in many countries, including developed ones, is the status of aboriginal peoples, for example in Australia, Canada and the USA among richer countries, and in Latin America, China and India among developing ones. Many communities in these countries were almost wiped out by policies close to planned genocides in some cases, and by neglect, displacement and disease in others. They often ended up demoralised, fragmented and with high levels of alcoholism and criminalisation. A particularly vicious sustained onslaught was that on native villagers in Guatemala between 1954 and 1995, conducted by militias and military with US assistance. Nevertheless, there have been some major improvements in the past decade, some of them proactively negotiated by governments, for example in New Zealand, and some concessions after years of pressure.

Thus the security agenda has extended beyond concerns with national borders to include 'non-traditional' security threats such as terrorism, organised crime, poverty, epidemics, drugs, hunger, natural disasters, illegal migration and refugees, environmental degradation, resource scarcity and poor governance. The view is sometimes expressed (although in our opinion it is a gross over-simplification) that 


\section{Box 1.2 The origins of the UK National Health Service and human security}

"This report argues that we are at such a point in the world's history today that we should be thinking revolutionary thoughts that will shape the next one hundred years of social progress" (Beveridge 1942).

"The UK's National Health Service (NHS) came into operation at midnight on 4 July 1948, US Independence Day. It was the first time anywhere in the world that completely free healthcare was made available on the basis of citizenship rather than the payment of fees or insurance premiums. The service has been beset with problems throughout its lifetime, not least a continuing shortage of cash, but having cared for the nation for half a century, most Britons consider the NHS to have been an outstanding success" (BBC 1998), with the promise that "everybody, irrespective of means, age, sex or occupation shall have equal opportunity to benefit from the best and most up-to-date medical and allied services available'. The services should be comprehensive and free of charge and should promote good health as well as treating sickness and disease. In purely medical terms the NHS has been an enormous success. One measure is in promoting longevity: men and women are living about 10 years longer on average than they did in 1948-men to 74 and women to 79. Despite its shortfalls, for the British it remains very popular and the top political priority.

The NHS was born out of the Dawson Report of 1920 which recommended a comprehensive system under the auspices of a single authority. The creation of the Emergency Medical Service in the Second World War added impetus and provided experience of how such universal healthcare, free at the point of delivery, might work in peacetime. In 1942 Sir William Beveridge, an eminent economist and first Director of the London School of Economics, identified a national health service as one of three essential elements of a viable social security system and pioneered the idea of human security at a time of threats to national security. War had brought the country together to focus on national priorities, just as climate change could be having the same galvanising effect today.

It is important to make the connection between social security, human security and national security. In his report, Beveridge makes the following comment:

"Organisation of social insurance should be treated as one part only of a comprehensive policy on social progress. Social insurance fully developed may provide income security: it is an attack on Want. But Want is only one of five giants on the road to reconstruction and in some ways the easiest to attack. The others are Disease, Ignorance, Squalor and Idleness (unemployment)" (Beveridge 1942: para 8). 
Canada and Norway emphasise a definition of human security summarised as 'freedom from fear', stressing protection against violence and the effective implementation of human rights; while Japan, in line with other Asian countries including China, puts more stress on 'freedom from want': that is, assuring basic livelihoods and access to food, water and medical care. Some theorists, however, object that the very broad definitions of human security make the term amorphous, almost meaningless, or at least impossible to realise.

The current debate in the USA on the provision of universal healthcare provides a real contrast with Europe's experience in this area of positive peace building. Europeans had experienced at first hand the depression and two wars and were clear in their common understanding of collectivism, shown in a negative, destructive way in the shared fight for national objectives which had killed near neighbours, brothers, sisters and lovers. William Beveridge, the author of a report on social security in the UK in 1942, which set the foundations for the National Health Service (NHS), said: "Now when the war is abolishing landmarks of every kind, is the opportunity for using experience in a clear field. A revolutionary moment in the world's history is a time for revolutions, not for patching' (Beveridge 1942).

It is no accident that the Europeans, Japan and New Zealand have by and large managed to develop the world's greatest economic global trade and social security nets (not for Japan) for all their populations with half the per capita carbon footprint of the USA, Canada and Australia and higher social cohesion, lower crime rate, greater democratic participation and greater longevity than the USA. After thousands of years of development and many centuries of war and economic recession some European nations have managed to develop a model of social democracy that delivers both quality of life and a high standard of living. Neither of the world's two largest economies, China and the USA, has so far managed to develop this level of sophistication and they may not even attempt to evolve in this direction unless the European model proves to be an irrefutably better system of organisation for a contemporary state and economy.

The Nobel Prize-winning economist Amartya Sen has written that 'to build a country, build a school' because the greatest acts of liberation and emancipation are derived from basic education and the enablement of access to information and democratic decision-making. In his writing over the last half century he has argued for fundamental rights as central to development (Sen 2002). Telling people they are free is not enough, telling people they can compete freely is not enough, and the absence of war is not enough. Positive peace is built on enabling structures and institutions that provide fundamental education and healthcare, founded on the principles of the rule of law, access to compensation and dispute resolution, and equal opportunities enshrined in human rights legislation. These aspects of community building can only be brought about by positive goals which seek to make resilience, social cohesion and mobility core characteristics of any civilised society. There are numerous examples of societies that have radically transformed themselves through applying these principles over the last century. Obvious postSecond World War examples are Japan, Costa Rica, Cuba and most of Europe-all 
places which now have high life expectancy, high life satisfaction, relatively high levels of social cohesion, and mid-to-low carbon footprints.

\section{The chapters in New Perspectives on Human Security}

Across all the chapters in this edited volume there are common foundational touchstones. Many make reference to the ideas of Roosevelt, Boutros BoutrosGhali, Kofi Annan, Amartya Sen and Sadako Ogata, the UNDP Report of 1994, and Michel Foucault on bio-governance. And these are indeed good places for the student of human security to start their investigation of the idea. Chapter 2 by David Roberts is subtitled 'The calculated mismanagement of life' and carries a theme that resonates in all the chapters: almost all human tragedies are avoidable. Just this thought alone is enough to light the fire of debate across the many 'security' discourses. Witness Paul D. Williams's Security Studies (Williams 2008: 1): 'The concept [of security] saturates contemporary societies all around the world'. Human security is sometimes seen as a subset within the security debate but, as this book attests, it is at the heart of all the other debates with its unapologetic focus on the person, on people and peoples and community. But, as Roberts says: 'Human security has been a hard kite to fly. Perhaps its greatest value is as a measurement of our civilisational advancement; or perhaps as an end-point of cumulative development'.

Chapter 3 by Hitomi Kubo echoes another theme that runs through these chapters: that human security represents a paradigm shift as it focuses on the individual rather than traditional notions of security based on the sovereignty of the nation. We must be careful of misusing Thomas Kuhn's understanding of paradigm shift as, when it comes to human security, the shift may be true more in the thinking than in the practice. In a sense this is what Kubo writes about: the problems of recreating and operationalising security from national security to human security. Kubo also helps us understand human security by looking at the concept from different perspectives: people-centred, comprehensive, intersectoral, prevention-focused and context-specific.

Roberts argues that 'it is clear that more honest appraisals of cause and effect in the international system can be derived from elements of Foucault's work on power as framework for thinking about human security and insecurity'. Foucault's work on bio-governance is one of the themes that runs across these chapters and leads to Hazel Barrett's chapter on HIV/AIDS and 'the rise of biopolitics'. She argues that HIV/AIDS has played a central role in 'the incorporation of health security within the new human security paradigm'. While Barrett's chapter is mostly focused on healthcare issues in Africa, Deepayan Basu Ray's chapter takes the human security paradigm to the world's largest and most financially prosperous nation and cri- 
tiques the lack of universal healthcare in the USA. In so doing Basu Ray and Barrett apply the human security paradigm to the richest and the poorest countries and show why this concept is so powerful in identifying individuals and communities within nation states who live in a state of fear and want. Also, in both their chapters they highlight the link between healthcare and governance, between fundamental human rights and GDP and governance and government.

Section III, on 'The environmental imperative, sustainable enterprise and human security', contains five chapters that make the link between business and human security with emphases on the natural environment, climate change, corporate responsibility and the emerging sustainable enterprise economy. Written in the immediate aftermath of the UN's Climate Change Conference in Copenhagen in December 2009, otherwise known as COP15, Chapter 6, by Malcolm McIntosh, seeks to learn some lessons from what has been described variously as a fiasco, a disaster and a missed opportunity by looking at the state of the world and trying to find new ways of co-creating a better future and developing a sustainable enterprise economy which incorporates the fundamentals of the human security paradigm.

Nicky Black's chapter runs through the development of voluntary corporate responsibility initiatives over the last decade and makes the link from them to the Millennium Development Goals (MDGs) and the concept of human security. She makes reference to Habermas's 'postnational constellation' and Zadek's 'civil market behaviour' and in doing so highlights once again one of the themes of this book: how we construct the post-state global governance given what we now know about ourselves, our success as a race and the state of the planet. The chapters by Black, and Yasunobu Sato and Dylan Scudder focus on one of the most imaginative but disputed voluntary initiatives of the past decade, that of the UN Global Compact (UNGC), which was designed to provide a learning space for business and the UN to think about how markets could help deliver the MDGs. ${ }^{3}$ Sato and Scudder want to add an 11th principle to the UN Global Compact:

Businesses should support concerted efforts by the United Nations and other international organisations to build and maintain peace and security; and support measures for conflict prevention and peacebuilding, and for protection of people in armed conflict, as well as empowerment of their capacity for human security at all times. ${ }^{4}$

The authors want to bring business and the UN together on human security by marrying the UN Global Compact to work being carried out in other parts of the

3 For background on the UN Global Compact and its history see McIntosh et al. 2004.

4 This working definition was first proposed by Professors Tatsuro Kunugi and Yasunobu Sato as an addition to the UNGC's ten principles and presented at a seminar held by the ARCHS (Applied Research Centre in Human Security) programme of Coventry University as part of the ESRC (Economic and Social Research Council) seminar series on human security in June 2008. 
UN on human security. Heaven forbid, now there's an idea: that the UN should work non-tribally!

Liliane Mouan and Miho Taka's chapters on oil in Angola and coltan mining in DRC, respectively, highlight the links between international business and human security and what has come to be known as the 'resource curse'. In the case of oil, exploration requires significant expertise and investment to make extraction viable, while coltan mining tends to be artisanal, but the supply chain issues are not dissimilar. Both products are vital to the working of the current global economy, both are strategic assets, and both tend to be located in areas of the world where extraction is difficult. And, both exemplify the categorisations that Kubo lists in Chapter 3 of this book.

In Chapter 11, Marci Green writes on conflict and human relations and community with perspectives that are new to the human security discourse. Attachment theory - 'a relational model of the mind and emotional development'-should, Marci Green argues, be part of the terrain of human security. This makes perfect sense when she reminds us that often development projects focus on hard infrastructure rather than soft emotional needs and social networks, which it is assumed will be delivered if children are sent to school, courthouses are built and clean water flows. Of course these things are important, indeed vital, in providing the infrastructure for human security, but how to build resilient, socially cohesive communities may be more to do with love than buildings. Which leads inexorably to Sarah Green and Alan Hunter's chapter on the disputed territory of reconciliation in Northern Ireland and a call for a better 'understanding of interface concerns to address the direct effects and disadvantages of violent conflict'.

Violence and keeping conflict at bay so that stability and positive peace become the norm are obviously central themes to human security, and Vesselin Popovski's introductory chapter to Section V on 'Human security and the responsibility to protect (R2P)' elaborates the links between this concept and human security. If, as Popovski says, human security broadly links a range of related issues which are common to all humanity at all times, then R2P 'only applies to [victims of] the most serious international crimes'. People might expect their state to protect them from genocide and mass murder, but the last 100 years has exposed this expectation as myth, since it is often the state that has committed these crimes. In these instances the world surely has a responsibility to protect innocent people; a commitment to protection of victims in such extreme circumstances, then, is a fundamental principle of human security and perhaps fundamentally challenges the legitimacy of the nation state and the UN's membership itself-although Popovski does not go as far as to state this conclusion.

Responsibility to protect (R2P) is the theme of the final three chapters by Bruce Baker, Manish Jha and Toru Sagawa. Baker's chapter analyses policing in Africa, or rather, the failure of policing. The police in many African states are part of an insidious culture of corruption where they fail to protect, fail to apply the law and act as a semi-lawless group dealing out arbitrary punishment. They are, Baker states, themselves often the perpetrators of human rights abuses. Manish Jha's chapter is 
set in the 'tribal hinterlands of India where the Maoists . . . are waging war against the state'. As he says, the human security paradigm calls on the state to serve the people, not the reverse, and in this conflict the state is found lacking in its ability to protect its people. Toru Sagawa's chapter is concerned with 'pastoralists in East Africa ... operating under a state without the capacity or will to protect its subjects'. This chapter neatly rounds off the book and brings us back to the main themes: the sanctity of the individual, the pervasive threats to human life and wellbeing, and the inability of the state in many cases, whether in the USA, India or the DRC, to protect its own people and provide the basic necessities of life. The chapters highlight the fact that it is possible to prevent almost all human tragedies, as Roberts argues. They implicitly raise a key point, often overlooked in writing on human security, that there are also many states and communities that do manage to deliver freedom from fear and freedom from want to large proportions of their populations. Celebration of these exemplars, and more importantly learning from them, is a key task for the future of human security.

\section{Conclusion: sustainable human security}

The sustainability imperative is now perhaps more critical than ever before: both scientific and public opinion recognises that the impacts of climate change, resource depletion and environmental degradation may soon radically transform our way of life. It is possible to argue that sustainability is the fourth revolution for humanity after the revolutions of agriculture, industrialisation and information. The 'human security' agenda will surely have to engage with these issues with increasing urgency. There are many signs that businesses are engaging with them also. This is partly in response to consumer pressure for ethical trading and lower carbon emissions, partly to cope with regulation and higher fuel costs, and for a variety of other reasons. The term 'sustainable enterprise' is becoming more widely used to denote the strategies involved in these developments and changes in the wider economy. We need to engage with a dynamic for sustainable human security. 


\section{References}

BBC (1998) 'The NHS: “One of the Greatest Achievements in History” ', news.bbc.co.uk/1/hi/ events/nhs_at_50/special_report/123511.stm, accessed 23 September 2010.

Beveridge, W. (1942) 'Beveridge Report on Social Insurance and Allied Services' (Cmnd 6404; London: HMSO): para 7.

Commission on Human Security (2003) Human Security Now (New York: Commission on Human Security; www.humansecurity-chs.org/finalreport/English/FinalReport.pdf, accessed 22 September 2010).

Evan, G., M Sahnoun, G. Côté-Harper and L Hamilton, (2001) 'The Responsibility to Protect' (Report of the International Commission on Intervention and State Sovereignty, December 2001; www.iciss.ca).

Jolly, R., and B. Ray (2006) The Human Security Framework (New York: UNDP).

Kaldor, M. (2007) Human Security: Reflections on Globalization and Intervention (Cambridge, UK: Polity Press).

Mani, D. (2002) Human Security: Concepts and Definitions (Tokyo: UN Centre for Regional Development).

McIntosh, M. (2006) 'Human Security Solutions Require Sustainable Enterprise', Compact Quarterly, November 2006; www.enewsbuilder.net/globalcompact/e_article000688256. $\mathrm{cfm}$ ? $\mathrm{x}=\mathrm{b} 11,0, \mathrm{w}$, accessed 23 September 2010.

— , S. Waddock and G. Kell (eds.) (2004) Learning to Talk: Corporate Citizenship and the Development of the UN Global Compact (Sheffield, UK: Greenleaf Publishing).

Owen, R. (2006) 'Ring of steel locks in immigrants', The Times, 11 August 2006; www. timesonline.co.uk/tol/news/world/europe/article605507.ece, accessed 22 September 2010.

Sen, A. (2002) ‘To Build a Country, Build a Schoolhouse', New York Times, 27 May 2002.

UNDP (1994) Human Development Report 1994: New Dimensions of Human Security (New York: UNDP).

Vollebaek, K. (1999) 'A Perspective on Human Security', Chairman's summary at the 1st Ministerial Meeting of the Human Security Network, Lysøen, Norway, 20 May 1999.

Williams, P.D. (2008) Security Studies: An Introduction (London: Routledge). 